\title{
Maria Bralewska
}

\section{The Tax Exemptions and Reductions in the Excise Duty on the Electricity in the Directive 2003/96/EC and the Polish Law}

\author{
Rola zwolnień i ulg podatkowych w zakresie opodatkowania \\ akcyzą energii elektrycznej w Dyrektywie 2003/96/WE \\ i jej implementacji w prawie polskim
}

\section{SUMMARY}

This paper discusses the functions of the tax exemptions and reductions in the excise duty on the electricity introduced in the Energy Directive (2003/96/EC) - being in the same time their ratio legis, and then analyzes the extent to which they have been implemented into the Polish tax law. In the course of the analysis the tax exemptions and reductions were divided into four groups, where the division criterion was the role that should be met in the economy: 1) the ecological tax exemptions and reductions, 2) supporting the competitiveness of the energy-intensive industries, 3) associated with the transport, 4) the social tax exemptions and reductions. The comparison of the legal norms expressed in the Directive with the standards contained in the Polish Excise Duty Act compels the conclusion that the numerous reliefs and exemptions in the excise duty on the electricity proposed by the Energy Directive are used in a very limited way in the Polish law.

Keywords: tax exemption and reductions; eco-tax; ecological taxation; excise duty

\section{INTRODUCTION}

When Poland joined the European Union, it became necessary to adjust Polish law to the EU regulations, including those in the field of the excise duty. As an indirect tax, this type of taxation has the particular importance for the proper functioning of the common market - therefore it remains in the EU's 
interest $^{1}$. Since the excise duties are levied only on some goods ${ }^{2}$, the catalog of the goods charged with the excise duty at the Community level is very important because of the need to adapt Polish regulations to it. Since 1992, when the compromise in regulating the excise duty was reached in the UE, the taxation concerned very limited group of goods: alcoholic beverages, tobacco and mineral oils. However, the so-called Energy Directive (the Directive 2003/96/EC) extended the list of the excisable products. In accordance with the provisions of the Directive, besides mineral oils the other energy products were subjected to the excise tax. The rules of the Directive also apply to the electricity. Taxing this group of products was motivated by environmental considerations ${ }^{3}$. Poland need not to extent the list of the excisable products provided by the Polish Excise Duty Act, because already in 2002, than two years before Polish accession to the EU, the electricity in Poland was taxed $\mathrm{d}^{4}$. However, the electricity is a special commodity as an article of first necessity ${ }^{5}$, which normally is not charged with excise duty ${ }^{6}$. Therefore, at the Community level the excise tax burden on the electricity produced "a complex mosaic of exemptions" ", whose functions we will try to explain in this paper. We also examine the extent of the Directive 2003/96/EC implementation in the Polish

1 L. Dick, Guide to the European Union, London 2005, p. 143.

2 Theory and Practice of Excise Taxation: Smoking, Drinking, Gambling, Polluting, and Driving, ed. S. Cnossen, Oxford 2005, DOI: http://dx.doi.org/10.1093/0199278598.001.0001, p. 2.

3 The excise duty on the electricity is treated as an environmental tax (see K. Lasiński-Sulecki, Akcyzy od produktów energetycznych $i$ energii elektrycznej w Dyrektywie 2003/96/WE a podatki ekologiczne, „Kwartalnik Prawa Podatkowego” 2006, nr 3-4, p. 79). However, criteria for distinguishing environmental from non-environmental taxes are different. Regarded as the most accurate definition of the environmental tax can be reproduced in the OECD's 1997 report, Environmental Taxes and Green Tax Reform, which stats that: "A tax falls into the category environmental if the tax base is a physical unit (or a proxy for it) of something that has a proven specific negative impact on the environment, when used or released" (cited from J. Snape, J. de Souza, Environmental Taxation Law, Abingdon, Oxon: Ashgate Publishing Group, 2006, p. 108)

4 The act of 15 February 2002 amending the Tax on Goods and Services and the Excise Duty Act of 8 January 1993 (Dz. U. 2002, No. 19, item 185) - now been repealed - expanded the catalog of goods liable to excise duty on electricity. The rate of tax amounted to $0.02 \mathrm{zl}$ per $1 \mathrm{kWh}$ (Article $37 \S 1 \mathrm{a})$.

5 Even if we accept that the electricity is not an article of first necessity, it undoubtedly is an indispensable asset for the cultural level of life of European nations. If you can do without alcohol and tobacco, even without a car, it is quite impossible to live in Europe on the contemporary level of civilization without electricity.

6 M. Kalinowski, Współczesne systemy podatkowe. Zarys wykładu, Toruń 1996, p. 79, cited from K. Lasiński-Sulecki, Prawna regulacja akcyzy w europejskim prawie wspólnotowym na tle teorii opodatkowania konsumpcji, Toruń 2007, p. 57.

7 T. Danescu, A. Dănescu, Competition Policy among the Energy Utilities and the Evolution of Liberalized Electricity Markets, "Economics, Management, and Financial Markets" 2010, No. 2, p. 262. 
law with regard to the tax exemptions and another form of the tax breaks provided by the Directive.

\section{THE ROLES OF EXEMPTIONS AND REDUCTIONS IN THE TAXATION ON THE ELECTRICITY}

Due to their function, the exemptions and reductions provided by the Energy Directive (both optional and mandatory ${ }^{8}$ ) can be divided into four groups: protecting the environment, supporting the competitiveness of the European economy and fostering the EU transport and social policy objectives - further we look at them closely.

\subsection{The ecological exemptions and reductions}

This group of tax exemptions and reductions is closely associated with the role played by the excise duty on electricity: by taxing the usage of the electricity, whose production is a significant contributor to the environmental pollution ${ }^{9}$, the excise tax is to lower its consumption ${ }^{10}$ and - as a result - to minimize greenhouse gas emissions from the production of the electricity. The EU was committed to reduce greenhouse gas emissions by the Kyoto Protocol" - the "agreement was reached that the United States, EU, and Japan should reduce the emission of global warming gases by $7 \%, 8 \%$, and $6 \%$, respectively, by the year $2010 " 12$. The taxation on the electricity was to achieve this goal - the $7^{\text {th }}$ section of the preamble in the Energy Directive informs us about it directly. The EU as a part of an international agreement such as the Kyoto Protocol was obliged to implement its provisions in

${ }^{8}$ Some of the exemptions provided by the Directive are obligatory - the Member States must introduce them into their tax system, but most of the exemptions and reductions are optional and their implementation depends on the assessment of the Member State. See Akcyza w orzecznictwie Europejskiego Trybunatu Sprawiedliwości, red. A. Kalinowska, S. Parulski, Warszawa 2006, p. 67.

${ }^{9}$ Environmental Policy Integration: Greening Sectoral Policies in Europe, ed. A. Lenschow, London 2002, p. 175.

${ }^{10}$ The excise duty is also used as a tool to influence the behavior of consumers of other goods which are harmful to health such as tobacco or alcoholic beverages. See OECD, Consumption Tax Trends 2010: VAT/GST and Excise Rates, Trends and Administration Issues, Paris 2011, p. 16.

${ }^{11}$ The second objective of the Directive was to ensure the proper functioning of the single market ( $\S 4$ and 5 of the Directive preamble). However, this goal was also an ecological one. With the taxation on the electricity launched for environmental reasons by some Member States, it became necessary to regulate this kind of tax at the level of the Community to protect the competitiveness of their economies. As a result, the EU has forced the countries, which until the notification of the Directive did not apply this environmental tax, to introduce it.

${ }^{12}$ Economy - Energy - Environment Simulation: Beyond the Kyoto Protocol, ed. K. Uno, Hingham 2002, p. 15. 
the EU law - in the form of the directive in this case, which had "the overall effect of what must be achieved, while the »form and the method « of the legislation is left up to the Member State to legislate"13.

So if the imposition of the tax has a negative impact on the consumption of the electricity produced in a harmful manner to the natural world, it is pointless to tax the electricity, whose production does not contribute to the environmental pollution. For this reason, the Directive 2003/96/EC implies the possibility to exclude from the excise duty the electricity of renewable sources - Article $15 \S 1(\mathrm{~b})$. Then from taxation may be exempted the electricity:

- of solar, wind, wave, tidal or geothermal origin,

- of hydraulic origin produced in hydroelectric installations,

- generated from biomass or from products produced from biomass,

- generated from methane emitted by abandoned coalmines,

- generated from fuel cells.

In Poland the option provided by the Directive has been into use for a maximum. The Polish Excise Duty Act prescribed a full exemption of the electricity generated from renewable sources from the excise tax.

However, taking into account the specific nature of the good, which the electricity is, the reduction of its consumption will be not always possible. Therefore, from an environmental perspective, the efficiency of the electricity use is extremely important - if you cannot opt out of the electricity, let the least greenhouse gas emissions associated with its production be minimal in relation to the benefits of its usage. On that account the Directive 2003/96/EC allows to exempt from the excise duty the electricity both used for combined heat and power generation and produced from this processes, provided that the combined generators are environmentally friendly.

Under the Polish legislation only the electricity used for combined heat and power generation is exempted from the taxation, but the noun of "power" laid down in the Directive was clarified and means only the electricity in the Polish regulations (Article $30 \S 6$ of the Excise Duty Act). However, the Polish Excise Duty Act does not mention the exemption for the electricity produced from combined heat and power generation.

It is also desirable to develop environmentally friendly technologies to increase the amount of energy from renewable sources and to improve the efficiency of using the electricity generated from traditional sources. Therefore the Directive permit to exempt from the excise duty the electricity consumed for pilot projects for the technological development of more environmentally-friendly products. It is also possible to exempt form the excise duty the electricity used in projects being

${ }^{13}$ B.W. Chambers, Inter-Linkages: The Kyoto Protocol \& the International Trade \& Investment Regimes, Tokyo 2001, p. 106. 
related to fuels from renewable resources. None of the above-discussed tax reliefs are found in the Polish law.

Caring for the Mather Nature two more tax breaks in the Directive are significant, which make possible to vary tax rates, when the differentiated rates are directly linked to product quality or depend on quantitative consumption levels for electricity used for heating purposes. The first of the reliefs is to encourage consumers to choose less energy-intensive products even if it entails their lower quality. If the product quality depends on the amount of the electricity needed for its production, for protection of the environment it is important to support via diminishing the tax rate the products of inferior quality but more environmentally-friendly by the lower consumption of the electricity during its production.

The latter breaks in the above paragraph permits the differentiated rates depended on the amount of electricity used for heating purposes. Although the Directive does not specify, what kind of a variation in the rate could be introduced in this case, taking into account the nature of the environmental taxes, which the excise duty takes in the Directive, we can assume that the greater consumption of electricity for heating purposes, the higher tax rate $^{14}$. This differentiation of tax rates is to stimulate the economy in the usage of the electricity for heating purposes, because even though the heat is a good of basic necessities, its production is undoubtedly harmful to the natural world - ergo, the less heated, the better for the environment.

Providing the reduction in tax rate for the above two cases, the Directive stipulates that the reduced rates have to respect the minimum level of taxation, but the Polish law orders no differences in the rate of taxation on electricity. Regardless of the amount of consumed electricity needed to produce a product, or used for heating purposes, the tax rate does not change in the Polish Excise Duty Act.

\subsection{In favour of the competiveness}

In addition to the tax exemption and reduction set out to encourage environmentally-friendly changes in the economy, the Directive provides a number of other tax reliefs - their purpose is to protect the competitiveness of the European economy. Taking into account the purpose of concessions made, this group seems to be the most interesting - indeed there is a paradox: on the one hand the excise tax is used as a tool to influence consumers for reducing the electricity consumption, on the other, the reliefs, or even exemptions, are granted to entities that consume the most electricity.

${ }^{14}$ Inputting the tax rebates in the excise duty on the electricity is not always guided by logic, as, for example, in relation to energy-intensive business, as we say in a next page, so it might be theoretically conceivable that the tax rate decreases with the increasing consumption. 
Looking to the excise tax from the standpoint of the consumption tax theory ${ }^{15}$, it seems reasonable to exempt from taxation the electricity used in non-consumption purposes. However, industry makes a significant contribution to pollute the biosphere, therefore the total exclusion from the excise tax - as an environmental tax - is impossible. Thus the Directive provides an intermediate solution: the different rates of taxation between non-business and business use. The rate for the industry is about half less than the rate for non-business: rates amounts for business-use 0.5 euro per $1 \mathrm{MWh}$ and for non-business 1 euro per $1 \mathrm{MWh}$ (Annex I, table C of the Directive 2003/96/EC). Moreover, $\S 2$ of Article 17 of the Directive allows the Member States to reduce even a $50 \%$ of the minimum tax rate for business-use, provided that companies, whose relief will apply to, commit to increase energy efficiency or to achieve another environmental objectives.

The $\S 1(b)$ of the aforementioned Article prescribes that even if the Member States decided to establish for the business-use the higher tax rate than the minimum, it can be reduced - without risking an accusations of discrimination against other businesses - for enterprises where agreements are concluded with undertakings or associations of undertakings, or where tradable permit schemes or equivalent arrangements are implemented, as far as they lead to the achievement of environmental protection objectives or to improvements in energy efficiency. This provisions of the Directive consistently confirmed the postulate expressed in its preamble: "(29) Businesses entering into agreements to significantly enhance environmental protection and energy efficiency deserve attention".

The Directive also grants the Member States the right of using incentives to protect those industries, which - due to its high energy consumption - will be particularly vulnerable to overloading the electricity excise tax. "At sectorial level, the energy intensive sectors are the most affected by the [environmental tax] policy"16. The possibility of exemptions for the entities the most contributing to activity, which would be limited by the imposed tax, raises the question about the purpose of such a regulation. However "the reason that energy-intensive industries are, against all environmental and economic logic, wholly or partially exempted from environmental taxes is because of fears of the negative impact of such taxes on these industries' competitiveness" ${ }^{17}$. Imposing new taxes, the consequences for the economy have to be taken into account, because it is not in anyone's interest to slow its development. Therefore "nations of the world need not sacrifice economic growth to protect the

${ }^{15}$ K. Lasiński-Sulecki, Prawna regulacja ..., p. 23.

${ }^{16}$ N. Kouvaritakis, L. Paroussos, D. van Regemorter, The Macroeconomic Evaluation of Energy Tax Policies within the EU with the GEM-E3-Europe Model, "Study for the European Commission DG TAXUD” 2003, p. 10.

${ }^{17}$ P. Ekins, S. Speck, Competitiveness and Exemptions From Environmental Taxes in Europe Department of Environmental Social Sciences, "Environmental and Resource Economics" 1999, No. 13, p. 385. 
environment"18. Besides, the incentives for energy-intensive are constrained to some limitations - they must respect the minimum level of taxation.

This requirement is not applicable only in one case - when enterprises enter into the agreements, tradable permit schemes or equivalent arrangements. These agreements, tradable permit schemes or equivalent arrangements must lead to the achievement of environmental objectives or increased energy efficiency, broadly equivalent to what would have been achieved if the standard Community minimum rates had been observed. (Article $17 \S 4$ ). If these conditions are fulfilled, the Directive allows the Member States to exempt even totally the energy-intensive business form the excise tax on electricity (Article $7 \S 2$ ).

Unfortunately, none of the above-mentioned regulations are implemented in the Polish law - in the Excise Duty Act there are no relief for businesses in general, nor supporting energy-intensive business, or companies committed to increase the energy efficiency. However, in recent years businesses have been lobbying hard for change in the Polish Excise Duty Act. Lacking a lot to catch up with the economies of Western Europe ${ }^{19}$, Poland deprived itself of opportunities to promote the competitiveness of its economy, so entrepreneurs protest, demanding the relief used in other European countries ${ }^{20}$. For now, however, in accordance with the assurances from the government, no amendment of the Excise Tax Act is anticipated. "According to the Ministry of Finance, the current excise tax rate slightly affects the costs of the activities carried on by the energy intensive industries and taking into account the nature of the quota rate, the share of excise taxes in the cost of production during the last few years was clearly decreased"21.

The only exemption designed to back the competitiveness of enterprises, having been introduced into the Polish legal system already in the Excise Duty Act of $2004^{22}$, concerned the energy companies producing electricity. In accordance

${ }^{18}$ H. Geller, Energy Revolution: Policies for a Sustainable Future, Washington 2002, p. 231.

${ }^{19}$ C. Enzler, R. Torres, G. Reinecke, Poland, Geneva 2001, p. 5.

${ }^{20}$ Reductions in the taxation of electricity for the energy-intensive business are applied by such countries as Denmark and Belgium. See: http://ec.europa.eu/taxation_customs/index_en.htm\# [accessed: 12.04.2015].

${ }^{21}$ M. Majkowska, Będą ulgi w akcyzie dla przedsiębiorstw energochłonnych, http://podatki. gazetaprawna.pl/artykuly/511995,beda_ulgi_w_akcyzie_dla_przedsiebiorstw_energochlonnych. html [accessed: 10.05.2015].

${ }^{22}$ Initially, the Polish tax law did not provide any tax relief from the excise duty on the electricity. Polish accession to the European Union in 2004 forced the adjustment of Polish law to EU regulations. Act of 01/23/2004 on Excise Duty (Dz. U. 2004, No. 29, item 257) introduced a total exemption from excise tax on energy from renewable sources - although this was not mandatory exemption under EU rules. The regulation of the Minister of Finance of April 26, 2004 (Dz. U. 2004, No. 97, item 966) introduced a further exemptions from the excise duty on the electricity used to produce electricity, to maintain the ability of its production, for combined heat and power generation, and for authorized entities exporting or supplying goods to another Member State. According to the regulation as eligible 
with the $\S 1$ (a) of the Article 14 of the Directive, the electricity used to produce the electricity and the electricity used to maintain the ability to produce the electricity shall be exempted from the excise duty. The requirement to introduce such a tax relief is not unconditional. The Directive allows Member States to tax the electricity consumed for purposes listed above, due to the environmental policy - in this case, however, the tax rate need not respect the minimum levels of taxation laid down in the Directive.

The introduction of incentives for companies producing electricity is related with the specificity of the electricity as a traded good. "Electricity is not economically storable, and production is subject to rigid short-term capacity constraints. Because demand is highly variable, this means there will be times when there is plenty of capacity, and the only incremental costs of producing electricity will be fuel and some operating and maintenance (O\&M) costs. At other times, the capacity constraint will be binding, causing the incremental cost to increase greatly and wholesale market prices to rise" ${ }^{\prime 23}$. Then the tax relief for enterprises generating electricity is to ensure the production profitability.

The list of the electricity usages, which the Directive does not apply to, can also function as the tax exemptions encouraging the competitiveness of business. They are listed in the $\S 4(b)$ of Article 2 under which the Directive shall not apply to the electricity:

- used principally for the purposes of chemical reduction and in electrolytic and metallurgical processes,

- when it accounts for more than $50 \%$ of the cost of a product,

- used in mineralogical processes.

Not charging the above-mentioned uses of the electricity with the excise duty can be explained by the concern for the competitiveness of so energy-intensive industries that even the reliefs set out in the Directive for this industrial sector may not be sufficient. The use of the electricity for the purposes of chemical reduction and in electrolytic, metallurgical and mineralogical processes is a key part of such

entities shall be those whose share of expenses related to the purchase of electricity in the deductible costs exceeds $18 \%$ in the billing month. Thus, the Excise Duty Act of 2004 provided relief to energy intensive companies operating in the European market. The Council Directive 2004/74/EC of April 29, 2004 amending the Directive 2003/96/EC about the application by new Member States, including Poland, temporary exemptions or reductions in the level of taxation on energy products and electricity, did not provide the transitional period to adjust Polish law to EU regulations in the field of excise duties on electricity. However, the transitional periods granted to adapt Polish legislation on taxation of other energy products obliged to another change in the regulations - the Excise Duty Act of 6 December 2008 (Dz. U. 2009, No. 3, item 11) - in force to today. In its provisions no longer relief in support of energy-intensive businesses is found.

${ }^{23}$ Electricity Deregulation: Choices and Challenges, eds. J.M. Griffin, S.L. Puller, Chicago 2005, p. 317. 
industry as aluminum, chemicals, forest products, glass, metal casting, mining, and steel, which are considered the highly energy-intensive industries ${ }^{24}$. The provisions are applicable to a product, where half the cost of its production is the price of electricity, witch concerns highly energy-intensive business by definition. Indeed, if - according to the Directive - the energy-intensive business is defined as a business entity, where either the purchases of energy products and electricity amount to at least $3.0 \%$ of the production value or the national energy tax payable amounts to at least $0.5 \%$ of the added value - Article $17 \S 1(\mathrm{a})$, the enterprise engaged in the production, where half the cost is the electricity price, meets the definition of the energy-intensive business with a surplus.

However, the treatment of the problem is extremely important, because the Directive does not provide the compulsory redundancies for those using of the electricity, but it states that the provisions set out in the Directive does not apply to those uses. According to the interpretation of the Polish legislator, if the above-mentioned uses of electricity are excluded from the scope of the EU's regulation, therefore they are left to settle for the Member States that follows from the division of the competence to legislate between the Union and the Member States. In the case of shared competence which we face in the regulation of environmental issues (Article $4 \S 2(\mathrm{e})$ of TFEU), the Member States shall exercise their competence to the extent that the Union has not exercised its competence ${ }^{25}$. The question is whether the exclusion of the above uses of the electricity from the excise duty by the Directive is nothing else than just the performance of its competence by the Union. Maybe the way in which the Polish government interprets the EU law is contrary to another rule binding the relations between Union and Member States: the principle of sincere cooperation and - closely connected with it - the rule of efficiency (effet utile). The decision on the matter remains with the Court of Justice of the European Union, if the entrepreneurs, in line with their statement, ask the Court in this case ${ }^{26}$.

Not only the industry could lose the ability to compete in world markets as a result of electricity taxation. Other areas of the European economy are equally susceptible to excessive taxation, especially agricultural, horticultural or piscicultural works, and in forestry. For this reason, the $\S 3$ of the Article 15 of the Energy

${ }^{24}$ Committee for Review of the Department of Energy's Industrial Technologies Program approved by the National Research Council: Decreasing Energy Intensity in Manufacturing: Assessing the Strategies and Future Directions of the Industrial Technologies Program, Washington: National Academies Press, 2005, p. 1.

${ }^{25}$ J. Barcz, M. Górka, M.A. Wyrozumska, Instytucje i prawo Unii Europejskiej. Podręcznik dla kierunków zarządzania i administracji, Warszawa 2011, p. 75.

${ }^{26}$ M. Pogroszewska, Zanosi się na kolejny spór o akcyzę na energię, www.rp.pl/artykul/ 419772-Zanosi-sie-na-kolejny-spor-o-akcyze-na-energie.html?template=restricted [accessed: 10.05.2015]. 
Directive allows to exempt entirely the electricity consumed for the purpose of the above mentioned sectors of the economy from the taxation. This tax relief also is not provided by the Polish Excise Duty Act.

\subsection{The electricity and the EU transport policy}

"Transport is a major user of energy"27. Of course, the other energy products than electricity are crucial for transport, but some of the tax reliefs from the excise duty on the electricity laid down in the Directive/2003/96/EC are important for the EU transport policy ${ }^{28}$. One of its objection is to promote more sustainable modes of transport than those which "contributes significantly to carbon dioxide emissions" 29 , thereby contaminating the environment.

More ecological mediums of transport shall be those driven by the electricity: first of all, the railway, but also the metro, trams and trolleybuses. The Directive give the possibility to exclude totally from the excise tax the electricity used to power those means of transport, both for the carriage of goods and passengers ${ }^{30}$.

All of the above-mentioned measures of transport are part of the public transportation, which associated with the EU transport policy purposes is backed as more environment friendly and promoting energy-efficiency ${ }^{31}$. "By having a lower rate of duty or an exemption for public transport vehicles, then this will lower operator costs, which could result in lower fares and enhanced services - so promoting modal shift" ${ }^{32}$. Therefore the Article 5 of the Directive gives the possibility of decreasing the tax rate for the electricity consumed by the local public passenger transport no matter what energy product drives the mode of transport. The rate of taxation, however, may not be less than the minimum.

The Polish Excise Duty Act does not provide the tax reliefs for the electricity used by public transport in general. However, another exclusion form the excise duty relating to transport had to be found in the Polish system, because the Directive obliges the Member States to impose the exemption for the electricity produced

${ }^{27}$ European Sector Futures, ed. J. Smith, Bradford 2004, p. 52.

${ }^{28}$ Although "fuel duty was never originally intended to be a transport policy measure. It emerged through the twentieth century to become a steady source of government income that fulfilled a series of important principles of taxation". See S. Ison, T. Rye, Implementation and Effectiveness of Transport Demand Management Measures: An International Perspective, Abingdon, Oxon 2008, p. 32.

${ }^{29}$ European Sector Futures, p. 52.

${ }^{30}$ It also includes taxis, which may be surprising, since taxis are not so energy-efficient means of transport. However, taxis play an important role in the nocturnal life of the city for safety reasons, so tax reductions permitted under the Directive reflect "conflict between security and a welcoming transport environment". See J. Cooper, R. Mundy, J. Nelson, Transport and Society: Taxi! Urban Economies and the Social and Transport Impacts of the Taxicab, Farnham, Surrey 2010, p. 184.

${ }^{31}$ G. Sabathil, K. Joos, B. Kessler, European Commission: An Essential Guide to the Institution, the Procedures and the Policies, London 2008, p. 160.

${ }^{32}$ S. Ison, T. Rye, op. cit., p. 35. 
on board a ship sailing on the Community waters other than pleasure private draft. It seems that this tax relief is a consequence of exempting from taxation the fuels used for these cruises, which are the energy product needed to produce electricity on board a ship. There is no regulations on the international scale, which would constrain the EU to introduce such provisions - as in the case of air flights, for which "Article 24 of the Chicago Convention prohibits the taxation of fuel used for international flights" ${ }^{33}$. However, water transport is of a great importance in some parts of Europe, where the only achievable way of communication is by ferry or ship and it is not possible to replace them with more environmentally friendly means of transport - instead of driving, we can take a train, in the case of ships such a cleaner replacement does not exist. However, due to the undoubted damage to the environment made by water transpor ${ }^{34}$, Member States may limit the scope of the exemptions provided for navigation to international and intra-Community transport. In addition, where a Member State has entered into a bilateral agreement with another Member State, it may also waive the exemptions provided for navigation. In such cases, Member States may apply a level of taxation below the minimum level set out in this Directive $-\S 1$ of the Article 14 .

\subsection{The special users of the electricity}

Although "social policy in the EU jargon means policy relating to labour relations" ${ }^{35}$ and as such "it has been of limited value to those whose access to labour markets was restricted, either because of their age, their dependent status, their need to provide care for others, their sickness, their disability, or even their lack of appropriate skills" ${ }^{36}$, however, the realization of its objectives goes beyond labour law in the strict sense. Also the tax law can be a tool for its implementation, and especially the system of tax exemption by release from paying taxes those, whom it is difficult to obtain funds to maintain, or to operate for various reasons - for example by the inability to enter the labour market, or by carrying on necessary but unprofitable business. Accordingly the Energy Directive allows to exempt from the excise duty the electricity used by the following consumers:

- disabled,

- caritable organisations,

- households.

${ }^{33}$ B. Daley, Air Transport and the Environment, Farnham, Surrey 2010, p. 79.

${ }^{34}$ M. Kaeding, Better Regulation in the European Union: Lost in Translation or Full Steam Ahead? The Transportation of EU Transport Directives Across Member States, Amsterdam 2007, p. 36.

${ }^{35}$ J. Pinder, S. Usherwood, European Union: A Very Short Introduction, Oxford 2007, p. 120.

${ }^{36}$ Europe, Policies, and People: An Economic Perspective, eds. S. Hatt, F. Gardner, Gordonsville 2002, DOI: http://dx.doi.org/10.1057/9781403907370, p. 153. 
For the disabled, Member States may exert the reduction of the tax rate, provided that it respects the minimum levels of taxation.

There are the specific grounds for exempting from the taxation the organization recognized as charitable by the Member State. They have a special status in a civil society, because "not motivated by or dependent upon profits can meet society's needs" ${ }^{37}$. Since they does not operate for profit, they must have other sources of financing and tax exemptions - for the organizations and for donors supporting them - are a form of enhancing charitable activities, moreover, very characteristic for them and having a long history ${ }^{38}$. Therefore the Directive give the Member States the possibility to exempt totally from the taxation the electricity used by charitable organizations. However, in order to avoid abusing of their special status, the nature of their activities should be subjected to special control of the Member States - Article $15 \S 1(\mathrm{~h})$.

The Directive also provides Member States the option of full exemption from excise tax on electricity used for household purposes. This is due to the difficulty - if not impossibility - of reducing consumption of electricity used to meet basic needs of every person.

Unfortunately, none of these exemptions has been included in the Polish Excise Duty Act.

Discussed above list of exemptions in the taxation of electricity as laid down in Directive 2003/96/EC is not closed: the Article 19 of the Directive foresees the way of its extension. This follows from the fact that the European Union currently consists of 27 member states - each of them has a different history, culture, but the tax system. Therefore, it may be necessary to establish additional incentives in some Member State for specific policy considerations.

\section{CONCLUSIONS}

Based on the above analysis we can conclude that the reductions and exemptions provided by the Energy Directive in the excise tax on the electricity have a very different functions. First of all, they are designed to put off the tax burden from the

${ }^{37}$ H.J. Bryce, Players in the Public Policy Process: Nonprofits as Social Capital and Agents, Gordonsville 2005, DOI: http://dx.doi.org/10.1057/9781403978233, p. 15.

${ }^{38}$ Nonprofit Sector: A Research Handbook, eds. W.W. Powell, R. Steinberg, New Haven 2006, p. 32 . 
electricity that does not contribute to environmental pollution, due to the nature of the eco-tax. Secondly, where reduction of the electricity consumption is impossible, the tax reductions and exemptions stimulate environmentally-friendly solutions, such as increasing the efficiency of electricity use, or promoting alternative means of transport. In the end, they are to protect certain entities from the excessive tax burden in the interests of their competitiveness on global markets (energy-intensive enterprises, agriculture, etc.), or because of their remarkable inability to pay any additional loads (charities, disabled), or finally due to the impossibility to avoid environmentally damaging activities (water transport).

The above features of the tax exemptions and reductions are the result of the compromise reached in response to the need for harmonization of electricity taxation. "National interests are mainly represented at the European level by the governments of the member states. They pursue policies which conserve national autonomy, are positively valued by their citizens, and protect consumers, foster employment and strengthens the competitiveness of enterprises in their country" 39 .

Poland's economy benefits from a very few of the many tax reductions and exemptions proposed in the Directive. In addition to the mandatory exemptions from the excise duty for the electricity produced on board a craft and used to produce electricity and to maintain the ability of its production, The Poland's Excise Tax Act provides the tax exemption only for the electricity generated from renewable sources and used for combined heat and power generation. In the Polish tax law no reliefs are found to support entrepreneurs in general, the energy-intensive business, other economic sectors as agriculture or those who have the particularly difficult to obtain funds for incurring additional charges.

After all it seems difficult to answer the question why it was considered that the Polish economy will cope without the help of state in the form of the excise tax reliefs on electricity, which the other - more developed - European economies guaranteed to themselves.

\section{BIBLIOGRAPHY}

Akcyza w orzecznictwie Europejskiego Trybunału Sprawiedliwości, red. A. Kalinowska, S. Parulski, Warszawa 2006.

Barcz J., Górka M., Wyrozumska M.A., Instytucje i prawo Unii Europejskiej. Podręcznik dla kierunków zarządzania i administracji, Warszawa 2011.

Bähr H., Politics of Means and Ends: Policy Instruments in the European Union, Farnham, Surrey 2010.

${ }^{39}$ G. Marks, F.W. Scharpf, P.C. Schmitter, W. Streeck, Governance in the European Union, London 1996, p. 20, cited from H. Bähr, Politics of Means and Ends: Policy Instruments in the European Union, Farnham, Surrey 2010, p. 21. 
Bryce H.J., Players in the Public Policy Process: Nonprofits as Social Capital and Agents, Gordonsville 2005, DOI: http://dx.doi.org/10.1057/9781403978233.

Chambers B.W., Inter-Linkages: The Kyoto Protocol \& the International Trade \& Investment Regimes, Tokyo 2001.

Cooper J., Mundy R., Nelson J., Transport and Society: Taxi! Urban Economies and the Social and Transport Impacts of the Taxicab, Farnham, Surrey 2010.

Daley B., Air Transport and the Environment, Farnham, Surrey 2010.

Danescu T., Dănescu A., Competition Policy among the Energy Utilities and the Evolution of Liberalized Electricity Markets, "Economics, Management, and Financial Markets" 2010, No. 2.

Decreasing Energy Intensity in Manufacturing: Assessing the Strategies and Future Directions of the Industrial Technologies Program, Washington: National Academies Press, 2005.

Dick L., Guide to the European Union, London 2005.

Economy-Energy - Environment Simulation: Beyond the Kyoto Protocol, ed. K. Uno, Hingham 2002.

Ekins P., Speck S., Competitiveness and Exemptions From Environmental Taxes in Europe Department of Environmental Social Sciences, "Environmental and Resource Economics" 1999, No. 13.

Electricity Deregulation: Choices and Challenges, eds. J.M. Griffin, S.L. Puller, Chicago 2005.

Environmental Policy Integration: Greening Sectoral Policies in Europe, ed. A. Lenschow, London 2002.

Enzler C., Torres R., Reinecke G., Poland, Geneva 2001.

Europe, Policies, and People: An Economic Perspective, eds. S. Hatt, F. Gardner, Gordonsville 2002, DOI: http://dx.doi.org/10.1057/9781403907370.

European Sector Futures, ed. J. Smith, Bradford 2004.

Geller H., Energy Revolution: Policies for a Sustainable Future, Washington 2002.

http://ec.europa.eu/taxation_customs/index_en.htm\# [accessed: 12.04.2015].

Ison S., Rye T., Implementation and Effectiveness of Transport Demand Management Measures: An International Perspective, Abingdon, Oxon 2008.

Kaeding M., Better Regulation in the European Union: Lost in Translation or Full Steam Ahead? The Transportation of EU Transport Directives Across Member States, Amsterdam 2007.

Kalinowski M., Wspótczesne systemy podatkowe. Zarys wykładu, Torun 1996.

Kouvaritakis N., Paroussos L., Regemorter D. van, The Macroeconomic Evaluation of Energy Tax Policies within the EU with the GEM-E3-Europe Model, "Study for the European Commission DG TAXUD" 2003.

Lasiński-Sulecki K., Akcyzy od produktów energetycznych i energii elektrycznej w Dyrektywie 2003/96/WE a podatki ekologiczne, „Kwartalnik Prawa Podatkowego” 2006, nr 3-4.

Lasiński-Sulecki K., Prawna regulacja akcyzy w europejskim prawie wspólnotowym na tle teorii opodatkowania konsumpcji, Torun 2007.

Majkowska M., Będa ulgi w akcyzie dla przedsiębiorstw energochtonnych, http://podatki.gazetaprawna.pl/artykuly/511995,beda_ulgi_w_akcyzie_dla_przedsiebiorstw_energochlonnych.html [accessed: 10.05.2015].

Marks G., Scharpf F.W., Schmitter P.C., Streeck W., Governance in the European Union, London 1996. Nonprofit Sector: A Research Handbook, eds. W.W. Powell, R. Steinberg, New Haven 2006.

OECD, Consumption Tax Trends 2010: VAT/GST and Excise Rates, Trends and Administration Issues, Paris 2011.

Pinder J., Usherwood S., European Union: A Very Short Introduction, Oxford 2007.

Pogroszewska M., Zanosi się na kolejny spór o akcyzę na energię, www.rp.pl/artyku1/419772-Zanosi-sie-na-kolejny-spor-o-akcyze-na-energie.html?template=restricted [accessed: 10.05.2015].

Sabathil G., Joos K., Kessler B., European Commission: An Essential Guide to the Institution, the Procedures and the Policies, London 2008.

Snape J., Souza J. de, Environmental Taxation Law, Abingdon, Oxon: Ashgate Publishing Group, 2006. 
Pobrane z czasopisma Studenckie Zeszyty Naukowe http://szn.umcs.pl

Data: 26/04/2023 16:49:30

The Tax Exemptions and Reductions in the Excise Duty on the Electricity...

Theory and Practice of Excise Taxation: Smoking, Drinking, Gambling, Polluting, and Driving, ed. S. Cnossen, Oxford 2005, DOI: http://dx.doi.org/10.1093/0199278598.001.0001.

\section{STRESZCZENIE}

W niniejszej pracy omówiono funkcje wprowadzonych w Dyrektywie energetycznej (2003/96/ WE) zwolnień i ulg podatkowych w zakresie opodatkowania akcyzą energii elektrycznej, stanowiące jednocześnie ich ratio legis, a następnie przeanalizowano, w jakim stopniu implementowano je do polskiego porządku prawnego. $\mathrm{W}$ toku analizy wyodrębniono cztery grupy zwolnień i ulg podatkowych, gdzie kryterium podziału stanowiła rola, jaką winny spełnić w gospodarce: 1) o charakterze ekologicznym, 2) wspomagające konkurencyjność szczególnie energochłonnych branż przemysłu, 3) związane $\mathrm{z}$ transportem, 4) społeczne. Porównanie treści norm prawnych wyrażonych $\mathrm{w}$ dyrektywie z normami zawartymi w polskiej ustawie o podatku akcyzowym zmusza do konstatacji, że z zaproponowanych w Dyrektywie energetycznej licznych ulg i zwolnień dotyczących opodatkowania akcyzą energii elektrycznej Polska gospodarka korzysta w bardzo ograniczonym zakresie.

Słowa kluczowe: ulgi i zwolnienia podatkowe; akcyza (podatek akcyzowy); opodatkowanie ekologiczne; eko-podatki; podatek ekologiczny 